other. It helps also in the search for methods to control abnormal growth : the action of radium on a tissue culture can show how it may be used most effectively in the treatment of cancer. The director's Report gives brief abstracts of the different researches at present in progress.

\section{Imperial Agricultural Bureaux}

THE fifth annual report (1933-34) of the Executive Council of the Imperial Agricultural Bureaux has now been published (London: H.M. Stationery Office, $4 s$. net). Consequent on the recommendations of the Imperial Committee on Economic Consultation and Co-operation (1933), the Council, in addition to its previous duties, has taken over the administration and financial control of the Imperial Institute of Entomology and of the Imperial Mycological Institute. Special prominence is given in this year's report to the work of these Institutes, and the degree of their activity may be judged by the fact that, on an average, more than 2,000 specimens a week have been received for identification by the former, and material has been forwarded from thirty-five Dominions and Colonies to the latter Institute during the year under review. The parasite laboratory at Farnham Royal, started by the Empire Marketing Board, has also passed under the control of the Council, and now draws common financial support. The work of the eight original bureaux continues to develop, and increased use is being made of the information services available by research institutes and research workers throughout the Empire.

\section{Madras Fisheries}

Dr. B. Sundara RaJ, director of fisheries, Madras, in his administration report for the year 1933-34 (Madras Fisheries Department), 1934, shows that the outstanding event of the year, which has brought back some measure of prosperity to the fishing industry of the west coast, was the return of the oil sardine in unexpected abundance after an absence almost complete for an unusually long series of years. The oil sardine (Sardinella longiceps) is the most important economic fish of the west coast, and its absence had reduced the fishermen to extreme poverty. Its return was just in time to save the industry from extinction, though advantage could not be taken of the abundance of the fish owing to the prevailing economic depression. Samples were examined twice a week and studied in detail. Research in all directions is progressing, an important result being the success obtained in keeping live pearl oysters under artificial conditions at the Krusadai Biological Station. This points to the possibility of establishing an oyster park which is one of the principal aims of this station. Oysterlings of 30-40 $\mathrm{mm}$. have lived in cages well over a year, during which several have grown to almost adult size $(50-65 \mathrm{~mm}$.). There is evidence of the larger oysters in the cages having spawned in captivity. Spawn has been found in the cages, and a pycnogonid found swarming in them had young microscopic oyster spat attached to the lateral processes. Special attention is being given to determination of age and rate of growth. Other investigations are in progress including a systematic survey of deep-sea fishing grounds by the trawler, plankton investigations, fish eggs and larvæ, daily collection of food fishes and hydrographical records, whilst technological research is not neglected. The whole report is exceedingly interesting and instructive, showing much activity in all directions.

\section{Literature of Food Investigation}

THE first number of vol. 6 of the "Index to the Literature of Food Investigation" reviews the developments during the years 1932-33 (Department of Scientific and Industrial Research: Index to the Literature of Food Investigation: Vol. 6, No. 1, March 1934. Compiled by Agnes Elisabeth Glennie, assisted by Owen Davies. London : H.M. Stationery Office, 1935. Pp. $309+\mathrm{v}$. 5s. net). One of the most important is the application of gas storage to meat : by increasing the amount of carbon dioxide in the atmosphere to $10-12$ per cent, it is possible to keep chilled meat in good condition for about seven weeks, so that chilled, instead of frozen, meat can be brought to Great Britain from so far away as New Zealand. Among other problems relating to animal products to which attention is directed are the onset of rancidity in stored food and the production and use of fish oils, which has assumed increasing importance with the development of our knowledge of the value of vitamins $\mathrm{A}$ and $\mathrm{D}$ as dietary factors.

Halibut liver oil is a rich source of vitamin $\mathbf{A}$, often 50-100 times as rich as cod liver oil: the liver oil of the ling cod may contain about eight times as much vitamin $\mathrm{D}$ as cod liver oil : the latter is not present in the liver oils of cartilaginous fish or in the liver fat of whales and other mammals. In the case of milk and milk products, reference is made to the pasteurisation of milk, the effect of processes of manufacture on the solubility of the protein of milk powders and the keeping qualities of butter. Interest continues to be shown in methods of freezing animal and vegetable tissues. Quick freezing has no advantage over slow freezing, so far as the palatability of meat is concerned, nor has it any advantage in the preservation of peaches, straw. berries or apple cider. Freezing orange and grapefruit juices does not usually affect the vitamin $\mathrm{C}$ potency. The importance of research into the problems of the storage and transport of fruit is shown by the fact that in 1932 more than 100,000 tons of oranges and 7 million bunches of bananas were brought to Great Britain in refrigerated ships, and emphasis is laid on the fact that the most satisfactory method of ascertaining the best storage temperatures for ocean transport is to make precisely controlled storage trials in the country of origin of the fruit.

\section{New 'House Number' Lamps}

The names of the streets round London are usually placed in a conspicuous position and are well lit by some neighbouring lamp, but in some of the side 